\title{
Motivasi Siswa Memilih Kompetensi Keahlian Desain Fesyen di SMK Negeri 3 Malang
}

\author{
Niluh Nur Afandi, Hapsari Kusumawardani*, Esin Sintawati \\ Universitas Negeri Malang, Jl. Semarang No. 5 Malang, Jawa Timur, Indonesia \\ *Penulis korespondensi, Surel: hapsari.kusumawardani.ft@um.ac.id
}

Paper received: 06-04-2021; revised: 20-04-2021; accepted: 24-04-2021

\begin{abstract}
The aim of this study was to describe students' motivation to choose Fashion Design at 3 Malang Vocational High School. This study used descriptive with quantitative approach. The number of respondents in this study were 69 students that consisted of X and XI grade students in Fashion Design. Intrinsic and extrinsic motivations used as sub variables in this study. To collect data, researches used questionnaire, that consisted of 33 questions. The validity test showed 0,495 and reliability testing showed 0,901 , it means the research questionnaire was valid and reliable. The results showed that the sub-variable intrinsic motivation was 71 percent, it means students intrinsic motivation influence by interests from themselves, and they developed their own talent to gain their carier in the future. In sub-variable extrinsic motivation was 66,7 percent, it means students extrinsic motivation influence by moral and material support from the family environment, support from the surrounding community and associates, a school environment has a good image, discipline, facilities, and infrastructure, and then in the form of job opportunities and certificates that will be obtained after graduate. Based on the result, it can be concluded that intrinsic motivation has a higher effect on student than extrinsic motivation. For better motivation for next new students, research sugested that Vocational High School must have good system to know the student motivation to choose special field before they jump in to Vocational High School. Psychology test can used to detect student talent and motivation in the future.
\end{abstract}

Keywords: motivation, fashion design skill, vocational high school

\begin{abstract}
Abstrak
Tujuan dari penelitian ini adalah untuk mendeskripsikan tentang motivasi siswa dalam memilih Kompetensi Keahlian Desain Fesyen di SMK Negeri 3 Malang. Rancangan penelitian ini menggunakan metode penelitian deskriptif dengan pendekatan kuantitatif. Jumlah responden yang digunakan dalam penelitian ini adalah sebanyak 69 siswa yang terdiri dari siswa kelas X dan XI Kompetensi Keahlian Desain Fesyen. Terdapat dua sub variabel yang digunakan pada penelitian, yaitu motivasi intrinsik dan motivasi ekstrinsik. Pengumpulan data menggunakan instrumen penelitian berupa angket yang terdiri dari 33 item pernyataan. Uji validitas diperoleh rata-rata nilai sebesar 0,495 dan uji reliabilitas diperoleh nilai sebesar 0,901, yang menunjukkan bahwa angket penelitian valid dan reliabel. Hasil penelitian menunjukkan bahwa pada sub variabel motivasi intrinsik diperoleh nilai sebesar 71 persen, hal itu berarti bahwa motivasi intrinsik siswa dipengaruhi oleh minat dari dalam diri siswa sendiri dan siswa ingin mengembangkan bakat yang dimiliki agar dapat mewujudkan citacita di masa depan. Pada sub variabel motivasi ekstrinsik diperoleh nilai sebesar 66,7 persen, hal itu berarti bahwa motivasi ekstrinsik siswa dipengaruhi oleh dukungan moral dan materi yang berasal dari lingkungan keluarga, dukungan yang berasal dari masyarakat sekitar dan teman bergaul, lingkungan sekolah yang memiliki citra, kedisiplinan, sarana dan prasarana yang baik, serta imbalan berupa peluang kerja dan sertifikat yang akan diperoleh setelah lulus. Berdasarkan hasil penelitian, dapat disimpulkan bahwa motivasi intrinsik memiliki pengaruh yang lebih tinggi terhadap siswa daripada motivasi ekstrinsik. Guna mengetahui motivasi yang lebih baik bagi siswa baru berikutnya, peneliti menyarankan bahwa SMK Negeri 3 Malang sebaiknya memiliki sistem yang baik untuk mengetahui motivasi siswa dalam memilih kompetensi keahlian sebelum siswa terjun ke sekolah. Salah satunya yaitu dengan mengadakan tes psikologi, agar dapat digunakan untuk mendeteksi motivasi dan bakat siswa di masa depan.
\end{abstract}

Kata kunci: motivasi; kompetensi keahlian desain fesyen; SMK Negeri 3 Malang 


\section{Pendahuluan}

Sesuai dengan Instruksi Presiden Nomor 9 Tahun 2016, yang menyatakan bahwa salah satu bentuk revitalisasi SMK yaitu dengan dikembangkannya kurikulum pendidikan. Kurikulum 2013 edisi revisi memiliki salah satu program baru yakni dibangunnya sistem pendidikan SMK dengan dua model, yaitu model SMK 4 tahun dan SMK 3 tahun. Pada pelaksanaan program pendidikan 4 tahun yang awalnya berbasis sekolah berubah menjadi berbasis Kompetensi Keahlian.

Kompetensi Keahlian Desain Fesyen merupakan salah satu kompetensi keahlian dari Program Keahlian Tata Busana yang memiliki program pendidikan 4 tahun. Salah satu SMK yang memiliki Kompetensi Keahlian Desain Fesyen adalah SMK Negeri 3 Malang. Berdasarkan hasil wawancara awal dengan Ketua Kompetesi Keahlian Tata Busana, SMK Negeri 3 Malang menyediakan kuota untuk 36 siswa setiap tahun. Pada tahun pertama, kuota Kompetensi Keahlian Desain Fesyen hanya terisi 33 siswa, berbeda dengan tahun kedua yang telah terisi sebanyak 36 siswa. Bertambahnya jumlah siswa yang memutuskan untuk memilih Kompetensi Keahlian Desain Fesyen, dari tahun pertama ke tahun kedua, merupakan salah satu bukti bahwa setiap siswa memiliki motivasi sendiri-sendiri yang mendorong untuk melakukan sesuatu dan memilih hal yang bermanfaat bagi dirinya.

Hasil wawancara yang telah dilakukan dengan siswa kelas X dan kelas XI Kompetensi Keahlian Desain Fesyen menunjukkan bahwa sebagian besar siswa mengungkapkan memiliki cita-cita ingin menjadi seorang desainer. Selain itu ada beberapa siswa yang menyebutkan bahwa keputusannya untuk memilih Kompetensi Keahlian Desain Fesyen yaitu karena disuruh orang tua, senang menggambar, bahkan ada yang hanya sekedar ingin mencoba. Oleh karena itu, penelitian ini bertujuan untuk mengetahui motivasi siswa dalam memilih Kompetensi Keahlian Desain Fesyen di SMK Negeri 3 Malang, mengingat pengaruhnya pada keberlangsungan program tersebut.

Motivasi merupakan dorongan yang timbul dari dalam diri, yang dapat menggerakkan hati seseorang untuk bertindak sesuai dengan keinginan, hingga dapat mencapai suatu tujuan (Purwanto, 2017). Motivasi memiliki tujuan dan fungsi tertentu, yaitu mendorong manusia untuk bertindak, memungkinkan manusia menjadi pelaku yang memiliki kehendak untuk melepaskan kekuatan yang dimiliki. Manusia juga berperan sebagai penentu arah atas perbuatan yang dilakukan. Arah tersebut dapat berupa tujuan atas keinginan yang hendak dicapai. Guna mencapai tujuan tersebut, dibutuhkan rencana-rencana berupa perbuatanperbuatan tersebut kemudian diseleksi agar mencapai tujuan yang diinginkan.

Berdasarkan jenisnya, motivasi dibedakan menjadi dua yaitu motivasi intrinsik dan motivasi ekstrinsik. Menurut Syah (2017) motivasi intrinsik merupakan keadaan yang berasal dari dalam diri, yang dapat mendorong seseorang untuk melakukan suatu tindakan tertentu. Motivasi intrinsik pada penelitian ini terdiri dari minat, bakat, dan cita-cita. Minat merupakan kecenderungan untuk lebih senang dan tertarik terhadap aktivitas tertentu, tanpa ada paksaan (Slameto, 2015). Pada penelitian ini, faktor minat mencakup perasaan senang, ketertarikan, pemusatan perhatian, dan keingintahuan. Menurut Syah (2017) bakat merupakan kemampuan potensial yang dimiliki setiap orang untuk mencapai keberhasilan pada masa mendatang. Pada penelitian ini, bakat meliputi upaya menyalurkan dan mengembangkan bakat. Hasil penelitian yang telah dilakukan oleh Abusyairi (2015) menyatakan bahwa cita-cita memiliki pengaruh yang kuat pada motivasi mahasiswa dalam menentukan program studi di universitas, karena 
cita-cita merupakan keinginan kuat yang dimiliki setiap orang untuk diwujudkan di masa depan. Sesuai dengan pernyataan tersebut, pada penelitian ini menggunakan indikator citacita yang terdiri dari upaya siswa dalam mewujudkan cita-cita.

Motivasi ekstrinsik menurut Maunah (2014) diartikan sebagai suatu dorongan yang timbul dari luar diri, yang dapat diperoleh melalui saran dan anjuran dari orang lain. Motivasi ekstrinsik dalam penelitian ini terdiri dari lingkungan keluarga, lingkungan sekolah, lingkungan masyarakat, dan imbalan. Menurut Syah (2017), keluarga merupakan tempat utama dan penting bagi tiap individu, karena melalui lingkungan keluarga inilah, individu pertama kali belajar melakukan segala sesuatu. Pada penelitian ini, lingkungan keluarga mencakup dukungan orang tua dan latar belakang keluarga. Lingkungan sekolah merupakan pendidikan utama yang kedua. Siswa, guru, dan warga sekolah lainnya hidup bersama dan melaksanakan pendidikan secara teratur dan terencana (Slameto, 2015). Pada penelitian ini, lingkungan sekolah mencakup citra sekolah, disiplin sekolah, kelebihan Kompetensi Keahlian Desain Fesyen, sarana dan prasarana. Menurut Slameto (2015) pengaruh lingkungan masyarakat terjadi karena keberadaan siswa dalam masyarakat. Pada penelitian ini, lingkungan masyarakat meliputi bentuk kehidupan masyarakat dan teman bergaul. Menurut Santrock (2014), imbalan merupakan karakteristik atau kualitas dari objek pemuas yang dibutuhkan seseorang yang dapat mempengaruhi motivasi atau merubah arah tingkah laku dari satu objek ke objek lain yang mempunyai nilai imbalan yang lebih besar. Pada peelitian ini, imbalan meliputi peluang kerja dan penghargaan yang diterima.

Kompetensi Keahlian Desain Fesyen merupakan salah satu kompetensi keahlian dari kelompok bidang keahlian pariwisata, khususnya pada Program Keahlian Tata Busana, yang menawarkan berbagai ilmu pengetahuan dan keterampilan yang berkaitan dengan dunia fashion. Kompetensi keahlian tersebut memiliki jumlah alokasi waktu sebanyak 6.648 yang terbagi ke dalam tiga muatan. Siswa pada Kompetensi Keahlian Desain Fesyen akan mendapatkan tambahan jam belajar pada beberapa kompetensi, seperti pembuatan hiasan dan desain busana. Tambahan jam pelajaran lainnya adalah pada mata pelajaran presentasi hasil karya, yaitu 18 jam dalam satu semester yang menuntut siswa dapat mendesain, menjahit, dan membuat pagelaran. Siswa harus dapat menampilkan hasil karyanya di depan umum dengan manajemen yang dikelola oleh siswa sendiri. Siswa Kompetensi Keahlian Desain Fesyen memiliki keterampilan yang lebih matang karena menjalani prakerin dua kali di tahun terakhir, dengan masing-masing selama empat hingga enam bulan. Selain itu, siswa Kompetensi Keahlian Desain Fesyen juga akan memperoleh sertifikat dari uji Lembaga Sertifikasi Profesi yang berada di level 3 dengan kompetensi ilmu manajemen sebagai pengusaha setelah lulus.

\section{Metode}

Rancangan penelitian ini menggunakan jenis penelitian deskriptif, dengan pendekatan kuantitatif. Populasi pada penelitian ini adalah seluruh siswa Kompetensi Keahlian Desain Fesyen di SMK Negeri 3 Malang, yaitu kelas X dan XI yang berjumlah 69 siswa. Keseluruhan dari populasi tersebut dijadikan sebagai responden penelitian, karena keterbatasan jumlah siswa yang menempuh pendidikan di Kompetensi Keahlian Desain Fesyen yang merupakan program baru.

Terdapat dua sub variabel yang digunakan sebagai ruang lingkup penelitian, yaitu sub variabel motivasi intrinsik dan sub variabel motivasi ekstrinsik. Pengumpulan data menggunakan instrumen penelitian berupa angket tertutup. Tahapan yang digunakan dalam 
penyusunan angket, yaitu membuat batasan-batasan terkait variabel dan sub variabel yang akan diukur, menjabarkan sub variabel menjadi indikator, menentukan kriteria pilihan jawaban yang sesuai dengan tiap butir pernyataan, dan menyusun butir pernyataan berdasarkan jabaran dari masing-masing indikator. Pengukur-an skala yang digunakan pada angket berupa skala likert dengan empat alternatif jawaban.

Validasi angket dilakukan oleh dosen Pendidikan Psikologi dan dosen Pendidikan Bahasa dan Sastra Indonesia, kemudian dihitung uji validitas dengan menggunakan rumus Korelasi Pearson (Product Moment) dan uji reliabilitas menggunakan rumus Cronbach's Alpha. Uji validitas diperoleh rata-rata nilai sebesar 0,495 dan uji reliabilitas diperoleh nilai sebesar 0,901, yang menunjukkan bahwa angket penelitian valid dan reliabel sehingga layak untuk digunakan. Uji coba pada penelitian ini menggunakan uji coba terpakai, yang berarti data hasil uji coba langsung dipakai sebagai data penelitian. Data yang telah diuji, kemudian diolah dan dianalisis.

\section{Hasil dan Pembahasan}

\subsection{Motivasi Intrinsik}

Sub variabel motivasi intrinsik terdiri dari tiga indikator dengan tujuh sub indikator yang didalamnya berisi 15 pernyataan. Ketiga indikator pada motivasi intrinsik terdiri dari minat, bakat, dan cita-cita. Hasil analisis data menunjuk-kan bahwa perolehan nilai rata-rata analisis deskriptif indikator minat diketahui sebesar 33.4 dengan kategori sangat tinggi. Perolehan nilai rata-rata analisis deskriptif indikator bakat diketahui sebesar 10.3 dengan kategori sangat tinggi. Perolehan nilai rata-rata analisis deskriptif indikator cita-cita diketahui sebesar 6.9 dengan kategori sangat tinggi. Secara keseluruhan, sub variabel motivasi intrinsik memperoleh nilai rata-rata sebesar 50.6 yang berarti dapat dikategorikan sangat tinggi.

Motivasi intrinsik terdiri dari indikator minat, bakat, dan cita-cita. Indikator minat terdiri dari empat sub indikator, yaitu perasaan senang, ketertarikan, pemusatan perhatian, dan keingintahuan, yang sebagian besar sangat berpengaruh terhadap motivasi siswa. Siswa merasa tertarik pada Kompetensi Keahlian Desain Fesyen karena merupakan program baru dengan masa tempuh pendidikan yang mencapai 4 tahun dan merupakan satu-satunya kompetensi keahlian tunggal di Kota Malang. Siswa juga merasa senang dengan memilih kompetensi keahlian tersebut, siswa dapat memperoleh pengalaman baru di bidang desain busana.

Keingintahuan yang kuat tentang Kompetensi Keahlian Desain Fesyen juga merupakan salah satu hal yang sangat berpengaruh bagi siswa. Siswa menyatakan sangat ingin mengetahui teknik dalam membuat busana, mulai dari teknik mendesain secara detail, menjahit busana, hingga mempresentasi-kan karya busana pada acara fashion show. Perasaan ingin tahu memang kerap sekali timbul dalam diri seseorang. Rasa ingin tahu akan senantiasa memotivasi seseorang untuk terus mencari dan mengetahui hal-hal yang baru sehingga akan memperbanyak ilmu pengetahuan, pengalaman, dan keterampilan dalam kegiatan belajar. Selaras dengan pendapat Syah (2017:136) bahwa seseorang yang memiliki minat akan cenderung merasa ingin tahu terhadap suatu hal yang besar dan memberikan perhatian yang lebih pada hal tersebut. 
Indikator bakat terdiri dari dua sub indikator, yaitu upaya siswa untuk menyalurkan bakat dan upaya siswa untuk mengembangkan bakat, yang menunjukkan hasil bahwa sebagian besar siswa menyatakan memiliki bakat yang sesuai dengan kompetensi keahlian yang dipilih. Siswa memilih Kompetensi Keahlian Desain Fesyen, karena melalui kompetensi keahlian tersebut siswa dapat menyalurkan bakat dengan cara menuangkan ide dan ekspresi melalui karya-karya desain busana yang dibuat. Selain itu, siswa juga dapat mengembangkan bakatnya, yaitu mengasah keahlian dalam mendesain dan menggali potensi dalam merancang busana, sehingga siswa semakin mahir dalam mendesain sebuah busana. Slameto (2015:57) mendefinisikan bahwa adanya bakat yang dimiliki oleh individu memungkinkan individu tersebut berkembang pada masa mendatang.

Indikator cita-cita terdiri dari satu sub variabel, yakni upaya dalam meraih cita-cita, yang secara keseluruhan sebagian besar siswa menyatakan memilih Kompetensi Keahlian Desain Fesyen karena memiliki cita-cita di masa depan. Siswa berkeinginan untuk menjadi seorang designer dan dapat memiliki prestasi pada bidang busana. Adanya cita-cita pada setiap diri seseorang, akan menimbulkan dorongan untuk merencanakan secara jelas mengenai arah dan tujuan hidup, serta senantiasa berupaya melakukan yang terbaik agar cita-cita tersebut dapat terwujud. Hal ini sesuai dengan hasil penelitian Abusyairi (2015:142) bahwa cita-cita sangat mempengaruhi motivasi mahasiswa dalam menentukan program studi. Berdasarkan pembahasan secara keseluruhan pada sub variabel motivasi intrinsik, dapat di interpretasikan bahwa motivasi intrinsik yang terdiri dari indikator minat, bakat, dan cita-cita sangat berpengaruh terhadap motivasi siswa dalam memilih Kompetensi Keahlian Desain Fesyen di SMK Negeri 3 Malang.

\subsection{Motivasi Ekstrinsik}

Sub variabel motivasi ekstrinsik terdiri dari empat indikator dengan sepuluh sub indikator yang didalamnya berisi 18 pernyataan. Keempat indikator pada motivasi ekstrinsik terdiri dari lingkungan keluarga, lingkungan sekolah, lingkungan masyarakat, dan imbalan. Hasil analisis data menunjukkan bahwa perolehan nilai rata-rata analisis deskriptif indikator lingkungan keluarga diketahui sebesar 9.0 dengan kategori tinggi. Perolehan nilai rata-rata analisis deskriptif indikator lingkungan sekolah diketahui sebesar 30.1 dengan kategori sangat tinggi. Perolehan nilai rata-rata analisis deskriptif indikator lingkungan masyarakat diketahui sebesar 7.5 dengan kategori sangat rendah. Perolehan nilai rata-rata analisis deskriptif indikator imbalan diketahui sebesar 10.2 dengan kategori sangat tinggi. Secara keseluruhan, sub variabel motivasi ekstrinsik mem-peroleh nilai rata-rata sebesar 56.8 yang berarti dapat dikategorikan tinggi.

Motivasi ekstrinsik terdiri dari indikator lingkungan keluarga, lingkungan sekolah, lingkungan masyarakat, dan imbalan. Indikator lingkungan keluarga terdiri dari sub indikator dukungan orang tua dan latar belakang keluarga, yang menunjukkan bahwa sebagian siswa menyatakan lingkungan keluarga berpengaruh pada motivasi. Siswa mengaku motivasi memilih Kompetensi Keahlian Desain Fesyen karena orang tua senantiasa mengarahkan dan mendukung segala hal yang berkaitan dengan masa depan. Bentuk dukungan tersebut berupa dukungan moral dan materi. Purwanto (2017:104) mengungkapkan bahwa keadaan ekonomi keluarga erat hubungannya dengan belajar anak, karena anak yang sedang menempuh pendidikan selain harus terpenuhi kebutuhan pokoknya, juga harus terpenuhi fasilitas yang digunakan untuk belajar. 
Indikator lingkungan sekolah memiliki empat sub indikator, yakni sekolah, disiplin sekolah, kelebihan Kompetensi Keahlian Desain Fesyen, serta sarana dan prasarana. Secara keseluruhan diperoleh hasil bahwa sebagian besar siswa menyatakan lingkungan sekolah sangat berpengaruh terhadap motivasi siswa. Lingkungan sekolah yang baik, akan menimbulkan persepsi yang baik pula terhadap sekolah tersebut, begitu juga sebaliknya. SMK Negeri 3 Malang telah terdaftar memiliki akreditasi A, selain itu kepala sekolah sangat disiplin dalam mengelola dan menerapkan peraturan, begitu juga dengan guru yang disiplin dalam mengajar dan memberikan pelayanan yang baik kepada siswa.

Siswa mengaku memilih Kompetensi Keahlian Desain Fesyen karena tersedianya sarana dan prasarana yang memadai, yakni terdapat laboratorium desain, dan laboratorium jahit. Kompetensi Keahlian Desain Fesyen juga memiliki beberapa kelebihan, antara lain siswa diajarkan secara lebih detail dan luas tentang ilmu desain busana, siswa juga di ajarkan agar dapat menampilkan karya busana dengan manajemen yang dikelola secara mandiri. Kelebihan selanjutnya yaitu siswa akan dibekali ilmu agar memiliki jiwa perintis usaha dan memiliki kemampuan bekerja sesuai bidangnya. Hal ini sesuai dengan tujuan didirikannya program pendidikan 4 tahun pada SMK, yaitu berjiwa perintis, memiliki kemampuan bekerja, dapat mengolah hasil pemikiran para ahli teknik, dan mampu memimpin para pelaksana teknik (Panduan Penyelenggaraan Program Pendidikan 4 Tahun Pada SMK, 2016:2-3).

Indikator lingkungan masyarakat terdiri dari dua sub indikator, yaitu bentuk kehidupan masyarakat dan teman bergaul. Secara keseluruhan diperoleh hasil bahwa sebagian siswa menyatakan lingkungan masyarakat berpengaruh rendah terhadap motivasi siswa. Siswa mengungkapkan motivasi memilih Kompetensi Keahlian Desain Fesyen bukan berdasarkan dari dukungan masyarakat maupun pengaruh pekerjaan dari masyarakat disekitar tempat tinggal. Hal ini dapat terjadi karena bagi generasi anak jaman sekarang, kegiatan bersosialisasi dengan masyarakat sekitar tidak sering dilakukan. Beberapa orang merasa kurang dapat mengakrabkan diri dengan masyarakat sekitar, sehingga tidak dapat mengenal lebih jauh tentang karakter dan pekerjaan yang dilakukan. Hal ini tidak selaras dengan pernyataan yang dikemukakan oleh A.M. Sardiman (2016:89) bahwa lingkungan masyarakat dapat menunjang dampak positif maupun dampak negatif pada suatu individu dan masyarakat dengan berbagai karakter, yang dapat mempengaruhi seseorang dalam mencapai kesuksesannya.

Hal berbeda diungkapkan oleh siswa bahwa motivasi dalam menentukan kompetensi keahlian ini sedikit banyak dipengaruhi oleh dukungan dan persepsi dari teman bergaul sehari-hari, namun sebagian siswa juga menyatakan bahwa teman bergaul tidak mempengaruhi motivasi. Teman bergaul memang memiliki pengaruh yang cukup besar bagi seorang siswa, sebab tidak jarang melalui pergaulan dengan teman yang begitu intensif, dapat mempengaruhi pola pikir seorang siswa terkait pilihannya. Slameto (2015:71) berpendapat bahwa pengaruh teman bergaul lebih cepat masuk dalam jiwanya. Teman bergaul yang baik akan memberikan pengaruh yang baik pula terhadap siswa, sebaliknya teman bergaul yang tidak baik akan memberikan dampak yang tidak baik pula pada siswa.

Indikator imbalan terdiri dari dua sub indikator, yakni peluang kerja dan penghargaan. Secara keseluruhan menunjukkan hasil bahwa sebagian siswa menyatakan sangat ingin memperoleh sebuah imbalan. Kompetensi Keahlian Desain Fesyen memiliki peluang kerja yang baik, karena selain dapat bekerja sebagai penjahit, lulusan kompetensi keahlian tersebut juga dapat menjadi designer pada suatu usaha busana. Peluang kerja selanjutnya yaitu, siswa 
dapat mendirikan sendiri usaha pada bidang busana yang diinginkan. Sebagian siswa memilih Kompetensi Keahlian Desain Fesyen juga karena adanya penghargaan yang diperoleh. Sesuai dengan pernyataan yang tertera dalam Panduan Penyelenggaraan Program Pendidikan 4 Tahun pada SMK (2016:21), bahwa untuk program pendidikan 4 tahun di SMK, siswa paling kurang memiliki kualifikasi KKNI jenjang 3, yaitu setara dengan Diploma 1. Lulusan program pendidikan 4 tahun akan diberikan sertifikat dari Uji Lembaga Sertifikasi Profesi yang berada di level 3 dengan kompetensi ilmu manajemen sebagai pengusaha. Hal ini selaras dengan teori A.M. Sardiman (2016:89) yang menyebutkan bahwa motivasi disebabkan oleh penghargaan/ penilaian dari orang lain, yang dapat mengakibatkan seseorang ingin berhasil.

Berdasarkan pembahasan secara keseluruhan pada sub variabel motivasi ekstrinsik, dapat di interpretasikan bahwa motivasi ekstrinsik yang terdiri dari indikator lingkungan keluarga, lingkungan sekolah, lingkungan masyarakat, dan imbalan berpengaruh terhadap motivasi siswa dalam memilih Kompetensi Keahlian Desain Fesyen di SMK Negeri 3 Malang.

\section{Simpulan}

Motivasi siswa memilih Kompetensi Keahlian Desain Fesyen di SMK Negeri 3 Malang ditinjau berdasarkan motivasi intrinsik dan motivasi ekstrinsik. Motivasi intrinsik sebagian besar sangat berpengaruh terhadap motivasi siswa dalam memilih Kompetensi Keahlian Desain Fesyen di SMK Negeri 3 Malang. Terdapat tiga indikator dalam motivasi intrinsik, yaitu minat, bakat, dan cita-cita. Ketiga indikator tersebut sama-sama sangat ber-pengaruh terhadap motivasi siswa. Namun, dari ketiga indikator tersebut, indikator yang berpengaruh paling tinggi terhadap motivasi intrinsik siswa adalah indikator cita-cita. Motivasi ekstrinsik sebagian besar berpengaruh terhadap motivasi siswa dalam memilih Kompetensi Keahlian Desain Fesyen di SMK Negeri 3 Malang. Terdapat empat indikator dalam motivasi ekstrinsik yaitu lingkungan keluarga menunjukkan cukup berpengaruh pada motivasi siswa, lingkungan sekolah menunjukkan sangat berpengaruh pada motivasi siswa, lingkungan masyarakat menunjukkan berpengaruh rendah pada motivasi siswa, dan imbalan menunjukkan sangat berpengaruh pada motivasi siswa. Berdasarkan keempat indikator tersebut, indikator yang memiliki pengaruh paling tinggi terhadap motivasi ekstrinsik siswa adalah indikator imbalan.

\section{Daftar Rujukan}

Abusyairi, K. (2015). Motivasi Mahasiswa dalam Memilih Prodi PBA Jurusan Tarbiyah STAIN Samarinda. FENOMENA, 7(1), 129-144.

Sardiman, A. M. (2020). Interaksi \& motivasi belajar mengajar.

Instruksi Presiden Republik Indonesia Nomor 9 (2016) Revitalisasi Sekolah Menengah Kejuruan Dalam Rangka Peningkatan Kualitas dan Daya Saing Sumber Daya Manusia Indonesia. (Online), (https://kemdikbud.go.id/main/files/download/e451d9ec3a04121) diakses 29 November 2018.

Maunah, B. (2014). Psikologi Pendidikan (Zahroh, Aminatul, Ed.). Tulungagung: IAIN Tulungagung Press.

Panduan Penyelenggaraan Program Pendidikan 4 Tahun Pada Sekolah Menengah Kejuruan Tahun 2016. Kementerian Pendidikan dan Kebudayaan Direktorat Pembinaan SMK. (Online), (http://psmk.kemdikbud.go.id/konten/2883/panduan-penyelenggaraan-program-pendidikan-4empat-tahun-pada-sekolah-menengah-kejuruan), diakses 29 November 2018.

Purwanto, M. N. (2017). Psikologi Pendidikan. Bandung: PT Remaja Rosdakarya.

Santrock, J. W. (2014). Psikologi Pendidikan. Terjemahan Harya Bhimasena. 2014. Jakarta: Salemba Humanika.

Slameto, S. (2015). Belajar Dan Faktor-Faktor Yang Mempengaruhi. Jakarta: Rineka Cipta.

Syah, M. (2017). Psikologi Pendidikan Dengan Pendekatan Baru. Bandung: PT Remaja Rosdakarya. 